\title{
Energy Independence and Research for Economic, Social and Environmental Sustainability
}

\author{
Paolo Tartarini
}

Department of Engineering “Enzo Ferrari” University of Modena and Reggio Emilia, via Vivarelli 10/1 41125 Modena, Italy

Corresponding Author Email: paolo.tartarini@unimore.it

https://doi.org/10.18280/ti-ijes.640106

Received: 9 December 2019

Accepted: 25 February 2020

\section{Keywords:}

energy, sustainability, sustainable development, scientific research, environment

\begin{abstract}
Climate change and global warming are destabilizing many human activities and affecting the economic development of our society. In this frame, sustainable development becomes a primary issue for our future, but the idea itself of sustainability must be founded on the intersection between economics, social needs and environmental requirements. Correct analyses on this subject should be based on key performance indicators, that have to be clearly defined and functionally connected.

The present paper is aimed at stressing out the fundamental indicators of sustainability and sustainable development. Its final goal, however, is to demonstrate that sustainable development cannot be achieved without a coordinated effort focused on deep research approaches by the scientific community.
\end{abstract}

\section{INTRODUCTION}

All functions and processes in the ecosystem of our planet are currently altered quite dramatically, and the main reasons can be summarized as follows:

- The biosphere receives humankind-produced materials faster than it can return them to the Earth's crust (e.g., coal, oil, minerals and metals, including lead and mercury).

- The human society produces potentially harmful and dangerous substances, like plastics, dioxins, DDT and PCBs, that are not broken down in acceptable timespans by natural processes.

- Our society predates ecosystems in such a fast way that they have no chances to regenerate the predated resources (e.g., trees, fish, fresh water).

- The man-made ecosystem manipulation (e.g., paving over fertile land, causing soil erosion, etc.) is seldom reversible.

All the above mentioned human acts degrade the ecosystem services and resources so heavily that no recovery can be foreseen within entire lifespans of people.

At the same time, many factors can erode the stability of our society: access to health, lack of competence, low levels of impartiality and equal treatment, corruption. All of those can badly affect the common trust in the systems and in the individuals, as well as in the organizations and institutions.

Last but not least, the interactions mankind-planet, together with the natural evolution of the climate during the centuries, appear to contribute to the onset of heavy anomalies that are currently well known under the names of climate change, global warming, etc. Some examples are shown in Figure 1, while a summary of extreme events and natural disasters from 1990 to 2016 is plotted in Figure 2.

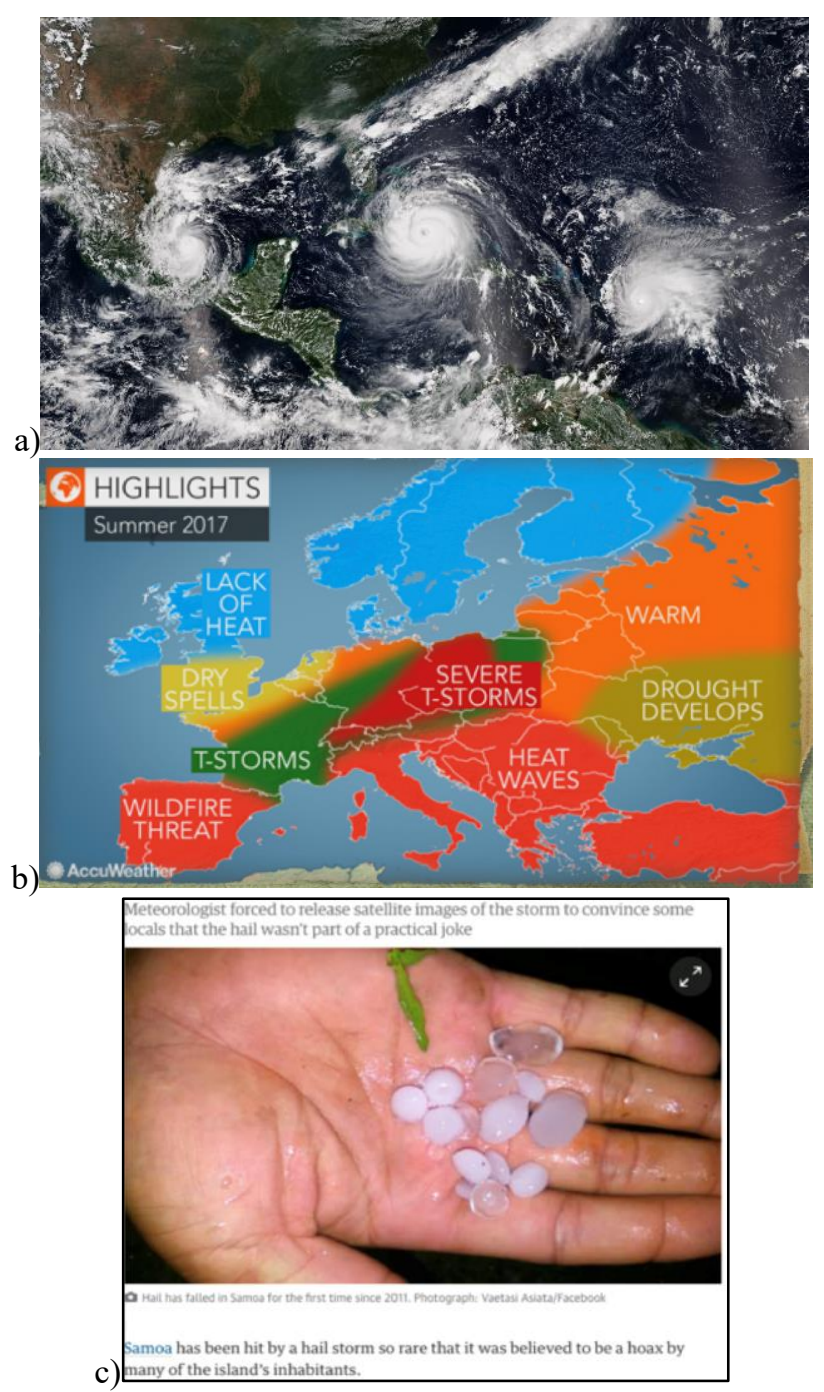

Figure 1. a) Simultaneous hurricanes in 2017 [1]; b) Summer 2017 in Europe [2]; c) hail in Samoa in 2016 [3] 


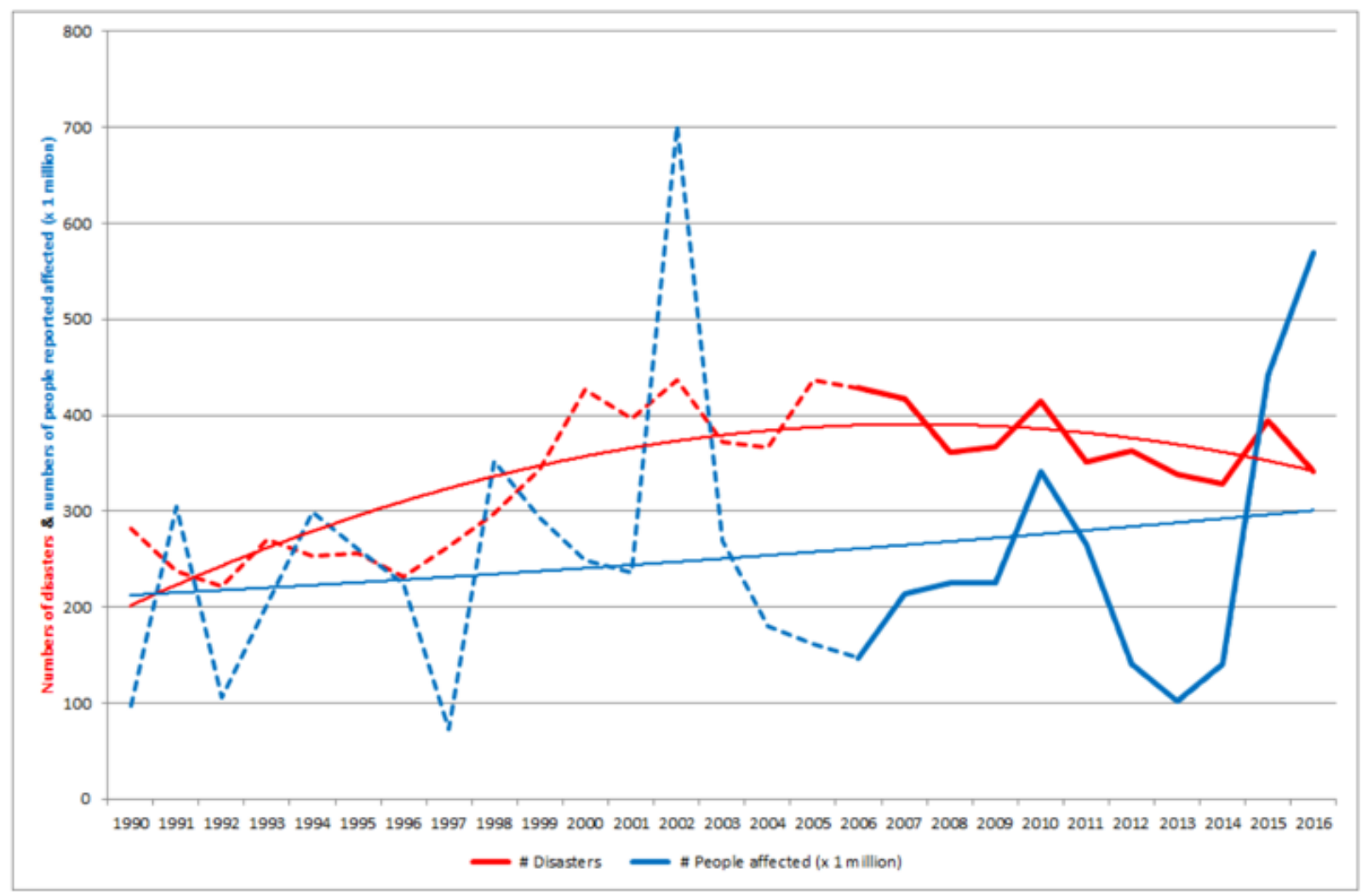

Figure 2. Numbers of disasters [red] and total people reported affected (x 1 million) [blue]: 1990-2016. Centre for Research on the Epidemiology of Disasters (CRED); Annual Disaster Statistical Review 2016 [4]

\section{SUSTAINABILITY DEVELOPMENT}

From the United Nations' "Press Kit for the Sustainable Development Summit 2015: Time for Global Action for People and Planet":

Sustainable development has been defined as development that meets the needs of the present without compromising the ability of future generations to meet their own needs.

For sustainable development to be achieved, it is crucial to harmonize three core elements: economic growth, social inclusion and environmental protection. These elements are interconnected and all are crucial for the well-being of individuals and societies.

The aforementioned definitions and considerations (graphically synthetized in Figure 3) appear to be a common background in the search for sustainable solutions for the development of our society.

In terms of search for solutions, a special mention is well deserved by the report Our Common Future, also known as the Brundtland Report in recognition of former Norwegian Prime Minister Gro Harlem Brundtland's role as Chair of the World Commission on Environment and Development (WCED).

This report was published in 1987 by the United Nations through the Oxford University Press. Its targets were multilateralism and interdependence of nations with the goal of defining a sustainable development path. It also tried to recapture the spirit of the Stockholm Conference, which had introduced environmental concerns directed to the political decision makers.

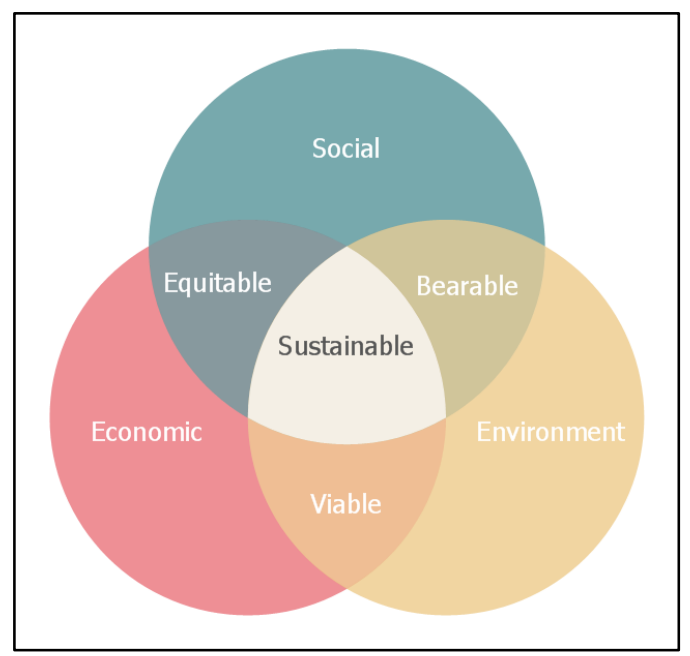

Figure 3. Sustainability as reported in the Report of the World Commission on Environment and Development "Our Common Future" United Nations 1987 [5]

\section{KEY PERFORMANCE INDICATORS (KPIs)}

In order to define and quantify the performance level of any action aimed at obtaining and improving sustainability and sustainable development, Key Performance Indicators (KPIs) are strongly needed.

In most cases, these indicators are strictly linked together, and very often the final result indicators are in close relationship with those who define structural characteristics of single countries or regions. A classical and famous example of 
this is the parameter known as Energy Intensity (as reported, for instance in "Global Energy Statistical Yearbook 2017, by Enerdata").

The energy intensity is calculated by dividing the total energy consumption of a country by its Gross Domestic Product (GDP). It measures the total amount of energy necessary to generate one unit of GDP. Total energy consumption includes coal, gas, oil, electricty, heat and biomass. GDP is expressed at constant exchange rate and purchasing power parity to remove the impact of inflation and reflect differences in general price levels and relate energy consumption to the real level of economic activity. Using purchasing power parity rates for GDP instead of exchange rates increases the value of GDP in regions with a low cost of living, and therefore decreases their energy intensities. World energy intensity of GDP in 2015 (country-by-country) is reported in Figure 4.

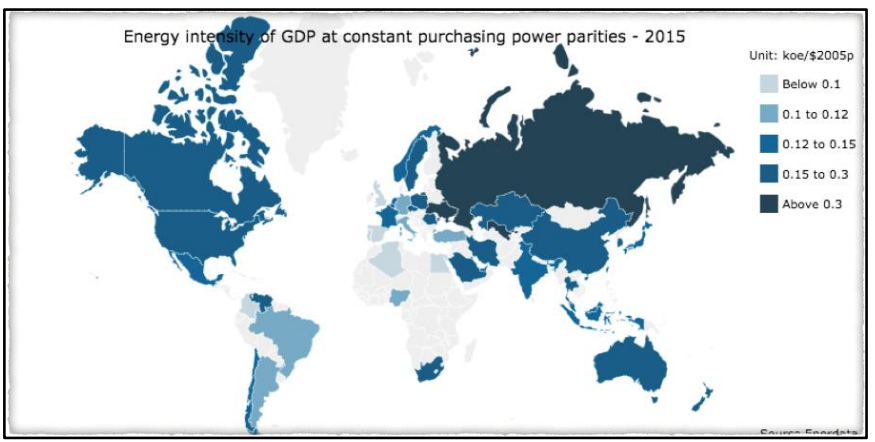

Figure 4. World Energy Intensity, 2015 [6]

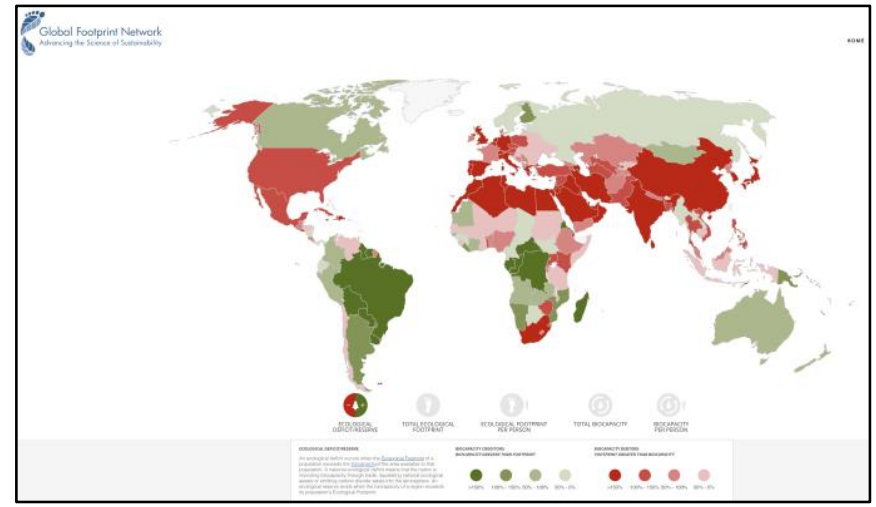

Figure 5. Global Footprint Network [7]

The World Energy Intensity reported in Figure 4 would remain a neutral statistical datum if it were not linked with other parameters, as, for instance, the Global Footprint Network graph reported in Figure 5. As stated inside the graph caption, "An ecological deficit occurs when the Ecological Footprint of a population exceeds the biocapacity of the area available to that population. A national ecological deficit means that the nation is importing biocapacity through trade, liquidating national ecological assets or emitting carbon dioxide waste into the atmosphere. An ecological reserve exists when the biocapacity of a region exceeds its population's Ecological Footprint."

In other words, the energy intensity of the GDP, which is a clear indicator of the economic and financial situation of a country, does not correspond, as Figure 4 shows, to a parallel "behavior" of that country in terms of ecological footprint.

Another important point to stress out concerning sustainable development is the population trend and the corresponding behavior of dietary trend, particularly in terms of protein consumption. The current projections of world population and the world protein consumption vs. population are reported in Figures 6 and 7 respectively.

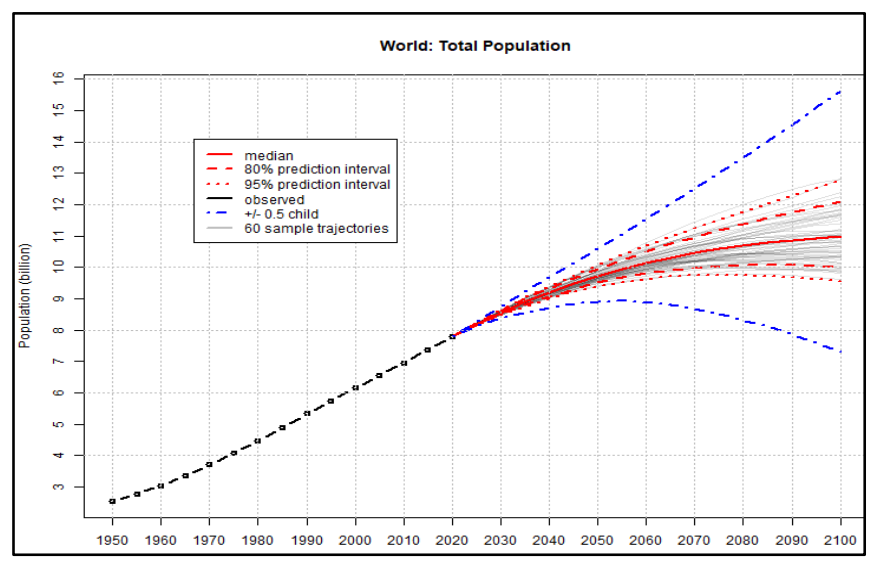

Figure 6. Projections of world total population [8]

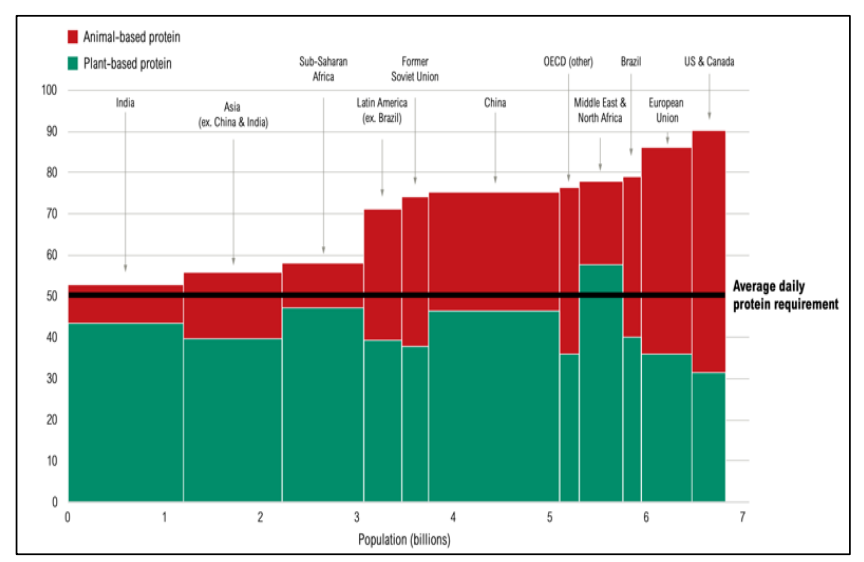

Figure 7. World protein consumption [9]

Overconsumption of protein occurs in all of the world's regions, and it is rising in developing and emerging economies. In 2009, the average person in more than 90 percent of the world's countries and territories consumed more protein than estimated requirements. Global average protein consumption was approximately 68 grams per person per day-or more than one-third higher than the average daily adult requirement. In the world's wealthiest regions, protein consumption was higher still. In addition, the share of animal-based protein is growing in people's diets relative to that of plant-based protein. Between 1961 and 2009, global average per person availability of animal-based protein grew by 59 percent, while that of plant-based protein grew by only 14 percent.

Looking forward, total consumption of animal-based food is expected to rise by nearly 80 percent between 2006 and 2050 . Although per person animal-based food consumption may be peaking in developed countries where consumption is already high, it is projected to rise in developing countries, especially in emerging economies and in urban areas. Like overconsumption of calories, overconsumption of protein widens the food gap. Furthermore, animal-based foods are typically more resource-intensive and environmentally impactful to produce than plant-based foods (Figure 2). Production of animal-based foods accounted for more than three-quarters of global agricultural land use and around two- 
thirds of agriculture's production-related greenhouse gas emissions in 2009, while only contributing 37 percent of total protein consumed by people in that year. Because many animal-based foods rely on crops for feed, increased demand for animal-based foods widens the food gap relative to increased demand for plant-based foods.

While agricultural expansion was pretty steady on a global scale for over 30 years, in 1995 we saw the first recorded decrease in agricultural land area. It peaked in 1998, and has been lower ever since. In fact, until 2015 (the latest year this data is available from the FAO) it was continuing to decline slightly over time.

The agricultural land use from 1961 to 2015 is reported in Figure 8 .

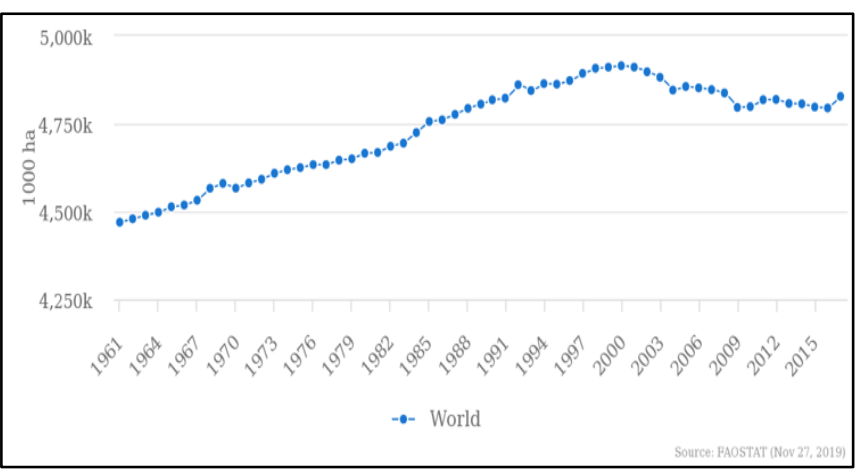

Figure 8. Agricultural land use [10]

Finally, sustainability should take into account also the rare earth elements (REE) production (see Figure 9), which, despite the spur in exploration activities, remains relatively small and still occurs predominantly from China.

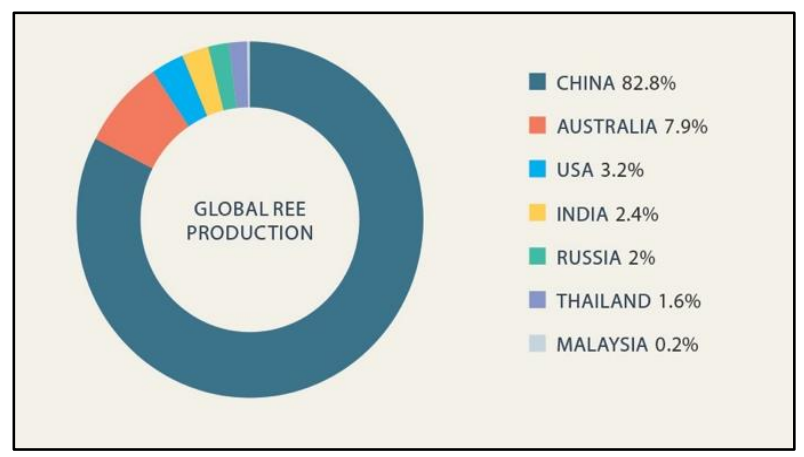

Figure 9. Global REE Production. Source: "An outlook on the rare earth elements mining industry", AUSIMM Bulletin, April 2016 [11]

\section{SUSTAINABLE DEVELOPMENT AND RESEARCH: THE ROLE OF THE SCIENTIFIC COMMUNITY}

The role of the scientific community in the general issue of sustainable development is well defined and analyzed by Luz M. Romo-Fernández, Vicente P. Guerrero-Bote and Félix Moya-Anegón, who, in their paper "World scientific production on renewable energy, sustainability and the environment", write: "Considering the countries with the greatest production, one observes that the highest values of cites per document correspond to Turkey, The Netherlands, Hong Kong, Taiwan, and Switzerland. With respect to the percentage of documents cited, Hong Kong is the country most often cited in relative terms, followed by Denmark, Sweden, and The Netherlands. The countries with the highest values of the normalized impact are Denmark, The Netherlands, Switzerland, Belgium, and Germany, all of which surpass the world average by more than $30 \%$. Tunisia, Jordan, Egypt, Nigeria, Russia, and Uzbekistan are the countries with the lowest values of normalized impact for the period studied, not exceeding $70 \%$ of the world average."

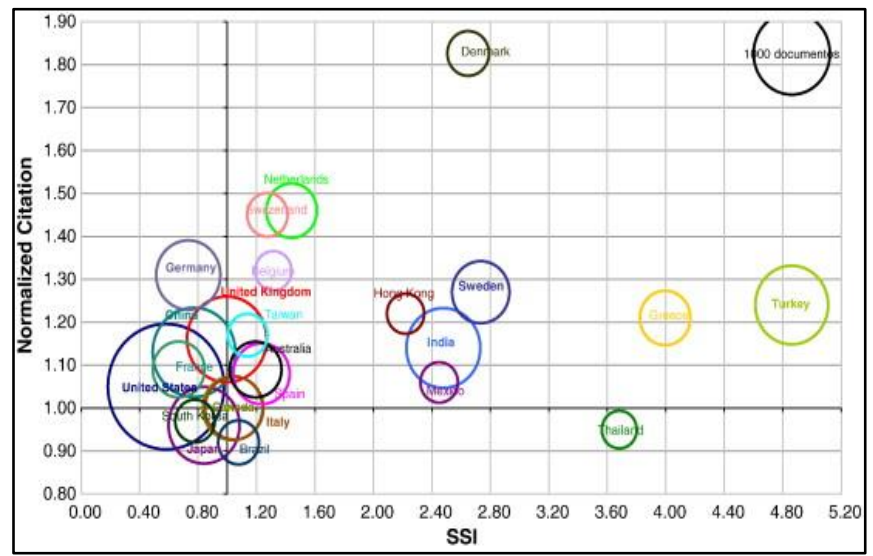

Figure 10. Subject specialization index and normalized impact of countries with a production of at least 200 documents (period 2003-08). The horizontal and vertical axes represent the global averages, and they are used to define the four quadrants [12]

This analysis, which is synthetized in Figure 10, effectively shows that the scientific community is working on the subject of sustainable development quite randomly. In other words, the world university rankings do not correspond to the rankings of scientific publications and citations in the field of sustainability. Moreover, no real coordination seems to exist at world level, and the scientific results appear to be totally disconnected from the industrial, social and environmental actions that take place in the countries where those scientific results are obtained.

The chaotic situation that characterizes the scientific contributions on sustainable development is dangerously similar to the one that characterizes policy decisions by world leading countries: for instance, European Union is quite focused (even if non unanimously) on general directives on sustainability, environment-friendly procedures and decarbonization standards in the energy sector; simultaneously, China is producing energy with any possible fossil fuel, United States are stepping out from any international agreement for the environment, and developing countries like India or Brazil appear to be zero-interested in sustainability intended as interaction of industrial development with social and environmental issues.

\section{FUNDAMENTAL GOALS FOR POLICY- AND DECISION-MAKERS}

The World Energy Council, in its 2016 World Energy Trilemma Report, has identified 5 main areas on which attention should be focused to guide progress towards a more effective practical translation of the energy securityenvironment-equity trilemma:

1) Transform the energy supply 
Policy makers need to identify clear and well-defined energy goals, and create a broad consensus to achieve this transformation. The use of pilot projects and analyses on the effectiveness of the policies adopted are fundamental tools for the creation of efficient and functional policies.

2) Increase access to energy

Many developing countries are working to expand energy infrastructure; to increase private investment, countries are also reforming regulatory frameworks to lower the costs of such investments. At the same time, distributed generation can arrive today in the most remote locations that cannot be reached by infrastructure in an economically sustainable manner. But expanding infrastructure is not enough, countries will have to look for innovative mechanisms to allow people to use energy and its benefits to start activities that generate revenue and economic development.

3) Increase economic accessibility

Many countries with low GDP and low levels of energy equity are working to improve the economic accessibility of energy, through funding or by creating contexts to attract investment and develop energy infrastructure. In the short term, state subsidies can be fundamental for less well-off consumers and to support social and development policies. But in the long term, subsidies can also be counterproductive, becoming very expensive, difficult to remove or reduce and could even stimulate inefficient uses of energy;

4) Increase energy efficiency and demand management

Efficiency and demand management are among the most important priorities worldwide, thanks to their enormous potential. However, the savings achieved alone are not always able to stimulate investments and efficient behavior: legislators must continue their commitment to align the interests of producers, users and regulators, through the combination of energy efficiency standards, labeling programs and incentives. They must also continue to increase awareness of energy efficiency both at the industrial and final consumer levels.

5) Decarbonization of the energy sector

COP21 gave a further boost to the global transition to a lowcarbon economy. Investment policies for a flexible and dynamic renewable generation are fundamental to respond to the evolution of market dynamics and technological developments. The objectives of COP2 1 will require a clear path to reach a significant and effective carbon price signal.

\section{CONCLUSIONS}

Nowadays, climate change and global warming are huge problems that can affect our present development and our entire future. The more negative effects of this scenario, however, regard only specific sectors of the earth population, because they will be particularly destabilizing on weak countries and weak social sectors, as well as they will be dangerously irreversible on environment and human health (which is differently accessible for different social sectors).

The answer to these problems can only be sustainable development, that has to be intended as a strong interaction between economic, social and environmental development.

A fundamental condition to obtain sustainable development is related to the common and coherent actions of policymakers and decision-makers, with particular attention to the behaviors of the world leading countries in terms of industrialization and energy intensity of the GDP. However, we believe that a more important success condition is strictly linked with the capability of the scientific community to coordinate and direct the necessary actions to realize sustainable development on the basis of science-based solutions as opposed to politics-based solutions.

The five points that the World Energy Council has identified as fundamental goals of our future are definitely well-posed and commonly acceptable, but the way to reach those goals should be scientific first and political next, never vice versa.

\section{REFERENCES}

[1] Tropical cyclones in 2017, Wikipedia, https://en.m.wikipedia.org/wiki/Tropical_cyclones_in_2 017, accessed on Jan. 17, 2020.

[2] 2017 Europe summer forecast: Heat to dominate the south; Storms to rattle Germany and Poland, https://www.accuweather.com/en/weather-news/2017europe-summer-forecast-heat-to-dominate-the-southstorms-to-rattle-germany-and-poland/70001611, accessed on Jan. 12, 2020.

[3] Samoa hit by hail storm so rare residents thought it was a hoax, The Guardian, 19 September 2016, https://www.theguardian.com/world/2016/sep/19/samoa -hit-by-hail-storm-so-rare-residents-thought-it-was-ahoax, accessed on Jan. 12, 2020.

[4] Annual Disaster Statistical Review 2016, Centre for Research on the Epidemiology of Disasters (CRED). https://emdat.be/sites/default/files/adsr_2016.pdf

[5] Report of the World Commission on Environment and Development "Our Common Future" United Nations 1987.

https://sustainabledevelopment.un.org/content/documen ts/5987our-common-future.pdf

[6] Global Energy Statistical Yearbook 2017, Enerdata. https://yearbook.enerdata.net

[7] Global Footprint http://data.footprintnetwork.org/\#/?

[8] United Nations, Department of Economic and Social Affairs, Population Division (2019). World Population Prospects 2019: Highlights (ST/ESA/SER.A/423).

[9] Shifting Diets for a Sustainable Food Future, Working Paper, World Resources Institute, https://wriorg.s3.amazonaws.com/s3fspublic/Shifting_Diets_for_a_Sustainable_Food_Future_ 1.pdf

[10] FAO stats, Food and Agriculture Organization of the United http://www.fao.org/faostat/en/\#data/RL/visualize, accessed on Jan. 17, 2020.

[11] An outlook on the rare earth elements mining industry, AUSIMM Bulletin, April 2016. https://www.ausimmbulletin.com/feature/an-outlookon-the-rare-earth-elements-mining-industry/, accessed on Jan. 17, 2020.

[12] Romo-Fernández, L.M., Guerrero-Bote, V.P., MoyaAnegón, F. (2012). World scientific production on renewable energy, sustainability and the environment. Energy for Sustainable Development, 16(4): 500-508. https://doi.org/10.1016/j.esd.2012.06.005 